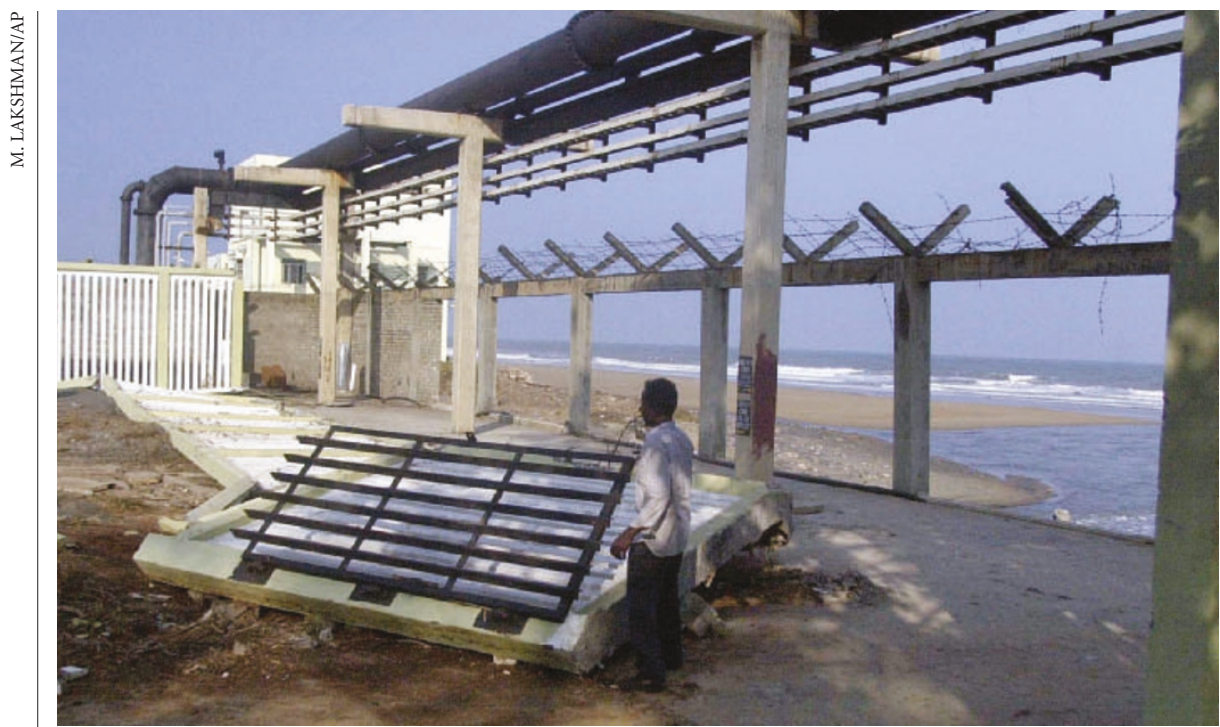

Safety first: the fast-breeder reactor at Kalpakkam, India, was submerged by December's tidal waves.

\section{India's nuclear debate hots up after tsunami floods reactor}

\section{K. S. Jayaraman, New Delhi}

India's nuclear regulator has called for a detailed report on the impact of December's tsunami on the nation's prototype fast-breeder reactor. The reactor's site at Kalpakkam in Tamil Nadu state was flooded by the wave, prompting fears about its future safety.

The Atomic Energy Regulatory Board wants to know whether it should modify the design of the Rs35-billion (US\$800-million) project - the centrepiece of India's nuclearenergy research programme - in light of the flood, which killed a construction worker.

Nuclear engineers say the flood shouldn't necessitate any major changes to either the siting or the design of the reactor, but critics are using the flood to reopen a debate about whether the ambitious project is appropriate to India's pressing energy needs.

Fast-breeder reactors were once widely regarded as the future of nuclear power. They rely on chain reactions that produce more fissile material than they consume.

India's prototype reactor at Kalpakkam would use sodium as a coolant and oxides of plutonium and uranium as fuel to produce $500 \mathrm{MW}$ of electricity. It is the first of five such reactors that India hopes to build by 2020, says Anil Kakodkar, secretary of the Department of Atomic Energy, after which it would switch to larger reactors.

But Ashok Parthasarathi, a science-policy specialist at Jawaharlal Nehru University in New Delhi, says the huge project demonstrates the unbalanced nature of energy policy in India. The country spends only about Rs150 million each year on research into renewable energy sources.
V. S. Arunachalam a former scientific adviser to India's defence department who is now at Carnegie Mellon University in Pittsburgh, Philadelphia, says that fast-breeder reactors will not be economically viable until the end of this century. And although France and Russia are still seeking to develop them, the United States, Britain and Germany have each abandoned fast breeders in the face of mounting costs, technical problems and the continued availability of cheap uranium for conventional nuclear reactors.

But Baldev Raj, who heads the Indian project, says the technology "is very much alive" internationally. He adds that India's decision to proceed is based on "experience gained from the design and operation" of a fast-breeder test reactor at Kalpakkam since 1987. Critics counter that the new reactor is 60 times bigger and relies on a different fuel.

Officials at the atomic-energy department say that India has a special need for the technology because it cannot buy uranium from abroad without agreeing to put all its nuclear facilities under International Atomic Energy Agency safeguards — something it has always refused to do.

The Kalpakkam project has been dogged by bad luck so far. India's prime minister, Manmohan Singh, missed a ceremonial pouring of concrete last August because of ill health.

S. K. Sharma, chairman of India's nuclear regulatory board, says that the tsunami has not exposed any particular safety risks at Kalpakkam. He predicts that any necessary design changes could be implemented before the project's 2010 completion date.

\section{Global geoscience suffers as UNESCO curtails funding}

Quirin Schiermeier, Munich

Geoscientists are protesting against proposed cuts to a small but successful international Earth-sciences programme.

The International Geoscience Programme (IGCP), which provides seed money for local projects, has helped thousands of geologists from developing countries to coordinate their work and liaise with colleagues around the world. It has long been seen as the star of the Earth-sciences division of the United Nations Educational, Social and Cultural Organization (UNESCO).

But changes are afoot. When UNESCO's Earth-sciences director retired in November he was not replaced. And according to information leaked to Nature, UNESCO is to cut annual funding to the IGCP, currently about US\$200,000, by almost half from 2006. The IGCP should still receive about $\$ 90,000$ a year from the International Union of Geological Sciences.

Walter Erdelen, UNESCO's assistant director-general for natural sciences, confirmed that there are plans to substantially reduce the programme, although he would not say by how much. He says UNESCO's science activities are focusing on water and ecology, following a reduction in the total budget for 2006.

This focus is fine, says Sospeter Muhongo, a geologist at the University of Dar es Salaam in Tanzania and newly elected chairman of the IGCP's scientific board. But he adds that geologists would have much to contribute to such work.

Members of the IGCP's scientific board issued a joint communication last week appealing to UNESCO to maintain current levels of funding. "Drastic cuts would be demoralizing," says Muhongo. A final decision will be made at UNESCO's executive board meeting in April.

Since 1972, some 500 regional geological and mining-related projects in 150 countries have received seed funding of up to $\$ 10,000$ from the IGCP. Although other projects exist to help geoscientists in developing countries (see Nature 433, $449 ; 2005)$, geologists say that the community will be sad to see one of the most established programmes cut.

"Almost all of the impact will be on scientists from developing nations," says Douglas Erwin, a palaeontologist at the Smithsonian Institution's Museum of Natural History in Washington DC. "It is short-sighted for UNESCO to do this.” Additional reporting by Rex Dalton, San Diego. 